\title{
SPECIFIC IgG AND IgM ANTIBODY RESPONSES IN HER PES-SIMPLEX-VIRUS INFECTIONS
}

\author{
J. B. KURTZ* \\ Virology Laboratory, Radcliffe Infirmary, Oxford
}

OF the wide variety of diseases caused by herpes-simplex virus (HSV) possibly the most severe is acute necrotising encephalitis, which is associated with a high mortality and, in the survivors, with varying degrees of permanent damage to the brain.

Recent advances in treatment (Juel-Jensen and MacCallum, 1972) have made obvious the need for early and rapid diagnosis. This at present rests on brain biopsy, with recognition of the presence of virus by immunofluorescence and culture. The detection of antibody in serum, early in the disease, is of no help in diagnosis because a high percentage of the population has antibodies against HSV.

In some other viral diseases, e.g., rubella and measles, the presence of specific IgM antibody in the serum has been interpreted as signifying recent or continuing infection (Haire and Hadden, 1970; Connolly, Haire and Hadden, 1971). The present work was undertaken to elucidate the antibody responses, both IgG and IgM, in primary HSV infections, oral and genital, in herpetic recurrences and in herpes-simplex encephalitis (HSE).

\section{MATERIALS AND METHODS}

Patients. Serum specimens were taken from nine patients with primary HSV infection, five of whom had oral lesions from which HSV, type 1, had been isolated and four of whom had genital lesions from which type-2 virus had been isolated; and from four patients with recurrent cold sores and one with recurrent genital lesions-all confirmed by virus isolation. Serum and CSF specimens were obtained from ten patients with HSE. The only sera available to us for testing from three of the patients (nos. 21, 23 and 24) had already been inactivated for $30 \mathrm{~min}$. at $56^{\circ} \mathrm{C}$. All specimens were stored at $-30^{\circ} \mathrm{C}$.

Complement fixing $(C F)$ antibody test. This was done by the standard technique, in WHO plates, using $3 \mathrm{MHD}$ of complement and overnight incubation at $+4^{\circ} \mathrm{C}$. The HSV antigen was either made in our own virus laboratory, by ultrasonic disruption of RK13 cells that had been heavily infected with type-1 herpesvirus, or obtained from the Standards Laboratory, Colindale.

Indirect-immunofluorescence antibody test. BHK21 cells were grown on cover slips and were then infected with a dose of a laboratory strain of HSV, type 1, that produced a $3+$ cytopathic effect after overnight incubation at $35^{\circ} \mathrm{C}$. After this time, the cover slips were washed in phosphate-buffered saline (PBS), fixed in acetone for $5 \mathrm{~min}$. and stored at $-30^{\circ} \mathrm{C}$ until used. Serum and CSF specimens for testing were absorbed with BHK21 cells $\left(1.5 \times 10^{8}\right.$ cells per $\mathrm{ml}$ of specimen) for 1 hour on a roller at $35^{\circ} \mathrm{C}$ and then overnight at $+4^{\circ} \mathrm{C}$.

Received 17 Oct. 1973; accepted 7 Nov. 1973.

* Present address: Public Health Laboratory, Heavitree, Exeter.

J. MED. MICROBIOL.-VOL. 7 (1974) 
Dilutions of serum or CSF were applied to BHK21 cells on cover slips and after incubation for 1 hour at $35^{\circ} \mathrm{C}$ these were washed with PBS for 1 hour at room temperature. Fluoresceinconjugated anti-human IgM or IgG (Burroughs Wellcome), which had been previously absorbed with BHK 21 cells, was then added for $30 \mathrm{~min}$. at room temperature. Preliminary tests had shown that fluorescein-conjugate dilutions of 1 in 8 and 1 in 40, respectively, gave the best contrast between non-specific background and specific fluorescence. After another wash in PBS, the cover slips were mounted in glycerol-PBS and examined with a Vickers "Patholette" microscope with tungsten-halogen lamp and interference filters. The antibody titre was the highest dilution of serum or CSF that gave distinct, specific fluorescence.

Some sera, described in the text, were also examined for IgM antibody after fractionation on sucrose-density gradients. Fractionation was done by layering $0.4 \mathrm{ml}$ of a 1 in 2 dilution on to a $10-40 \%$ (w/v) sucrose gradient, centrifuging overnight at 35,000 r.p.m. in a $3 \times 5 \mathrm{ml}$ swing-out rotor of a Super Speed 40 Centrifuge (MSE) and collecting twelve fractions. Fraction no. 2, which contained IgM but no IgG, as shown by double diffusion against antiIgM and anti-IgG antisera (Behringwerke), was examined for anti-HSV IgM antibody by indirect immunofluorescence as already described. The concentration of total IgM in this fraction, as well as in the original whole serum, was also measured in S-Partigen-IgM immunodiffusion plates (Behringwerke).

\section{RESULTS}

\section{Antibody responses in patients with primary HSV infection}

Because some of the sera available to us for testing had already been inactivated, we studied the effect of heating at $56^{\circ} \mathrm{C}$ for 1 hour on HSV-specific IgM antibody levels, with four sera known to contain such antibody. As no reductions in antibody titre were found, we felt justified in accepting the tests for IgM antibody on the inactivated sera as reliable.

As shown in table I, primary infection, oral and genital, was always followed by the appearance of both IgG and IgM antibody, and in four patients antibody was detected earlier by immunofluorescence than by complement fixation. IgG antibody, as measured by immunofluorescence, had usually appeared by the 5th day, increased to a titre of 64-128 and persisted throughout the period of observation. One patient, no. 6, whose CF antibody titre had decreased to $<4$ after 400 days still had an immunofluorescent-IgG titre of 16 . In no case was IgM antibody detectable before IgG, and even in the earliest specimens the IgG titre was always higher than the IgM. Whilst this might be due to different sensitivities of the techniques used to measure IgG and IgM antibody, the same techniques applied to a patient with measles on the 3rd day of illness, with Vero cells infected with the Edmonston strain of measles virus as antigen, gave a measles IgM-antibody titre of 16 with $\mathrm{IgG}$ antibody detectable only in undiluted serum and a CF antibody titre of $<4$.

The IgM-antibody titre reached at least 16 in all of the patients, except no. 5 from whom a serum specimen could be obtained only on the 6th day of illness. Two patients (nos. 1 and 7) still had a titre of 8 as late as 53 and 57 days, and patient 2 had a titre of 16 after 188 days without any clinical recurrence of her herpes infection. To exclude the possibility that these might be false readings due to rheumatoid factor (Fraser, Shirodaria and Stanford, 1971), sera were retested after absorption with aggregated IgG but the titres remained unchanged. Three patients (nos. 6, 7 and 9), who were re-examined 80, 250 and 400 days 
respectively after the onset of illness, then had IgM antibody titres of only 2 or less, as found in patients with a history of recurrent herpes (see below).

TABLE I

Serum-antibody responses in primary herpes-simplex-virus infection

\begin{tabular}{|c|c|c|c|c|c|c|}
\hline \multirow{2}{*}{$\begin{array}{l}\text { Patient } \\
\text { number }\end{array}$} & \multirow{2}{*}{$\begin{array}{c}\text { Age } \\
\text { (years) }\end{array}$} & \multirow{2}{*}{$\begin{array}{l}\text { Virus } \\
\text { type }\end{array}$} & \multirow{2}{*}{$\begin{array}{l}\text { Day of } \\
\text { illness }\end{array}$} & \multicolumn{3}{|c|}{ Antibody titres } \\
\hline & & & & $\begin{array}{l}\text { Complement- } \\
\text { fixing }\end{array}$ & IgG* & IgM $^{*}$ \\
\hline 1 & 20 & 1 & $\begin{array}{r}5 \\
10 \\
14 \\
53\end{array}$ & $\begin{array}{r}<4 \\
8 \\
32 \\
32\end{array}$ & $\begin{array}{l}<4 \\
32 \\
64 \\
64\end{array}$ & $\begin{array}{r}<2 \\
8 \\
16 \\
8\end{array}$ \\
\hline 2 & 21 & 1 & $\begin{array}{r}-90 \\
5 \\
10 \\
77 \\
188\end{array}$ & $\begin{array}{r}<4 \\
16 \\
64 \\
128 \\
128\end{array}$ & $\begin{array}{r}<4 \\
16 \\
64 \\
128 \\
64\end{array}$ & $\begin{array}{r}<2 \\
4 \\
8 \\
16 \\
16\end{array}$ \\
\hline 3 & 27 & 1 & $\begin{array}{r}4 \\
8 \\
15\end{array}$ & $\begin{array}{r}<4 \\
32 \\
64\end{array}$ & $\begin{array}{r}4 \\
16 \\
128\end{array}$ & $\begin{array}{r}<2 \\
4 \\
16\end{array}$ \\
\hline 4 & 2 & 1 & $\begin{array}{r}5 \\
10\end{array}$ & $\begin{array}{r}<4 \\
64\end{array}$ & $\begin{array}{r}4 \\
128\end{array}$ & $\begin{array}{r}4 \\
16\end{array}$ \\
\hline 5 & 18 & 1 & 6 & $<4$ & 16 & 8 \\
\hline 6 & 43 & 2 & $\begin{array}{r}8 \\
32 \\
400\end{array}$ & $\begin{array}{r}<4 \\
16 \\
<4\end{array}$ & $\begin{array}{r}<4 \\
32 \\
16\end{array}$ & $\begin{array}{r}<2 \\
16 \\
2\end{array}$ \\
\hline 7 & 26 & 2 & $\begin{array}{r}4 \\
6 \\
15 \\
57 \\
250\end{array}$ & $\begin{array}{l}<4 \\
16 \\
64 \\
64 \\
64\end{array}$ & $\begin{array}{r}32 \\
128 \\
128 \\
128 \\
64\end{array}$ & $\begin{array}{r}8 \\
16 \\
32 \\
8 \\
2\end{array}$ \\
\hline 8 & 29 & 2 & $\begin{array}{r}2 \\
15\end{array}$ & $\begin{array}{l}<4 \\
128\end{array}$ & $\begin{array}{l}<4 \\
128\end{array}$ & $\begin{array}{l}<2 \\
32\end{array}$ \\
\hline 9 & 33 & 2 & $\begin{array}{r}4 \\
24 \\
80\end{array}$ & $\begin{array}{r}<4 \\
128 \\
64\end{array}$ & $\begin{array}{l}<4 \\
256 \\
128\end{array}$ & $\begin{array}{l}<2 \\
32 \\
<2\end{array}$ \\
\hline
\end{tabular}

* Estimated by indirect immunofluorescence.

Antibody titres in patients with recurrent herpes

All five patients had CF and immunofluorescent-IgG antibody (table II), similar titres being obtained by both methods. Only two of the five patients had 
detectable IgM antibody at levels of 2. Only undiluted serum from the three other patients gave some reaction with the anti-IgM conjugate, but the staining was faint and it is uncertain whether this represents traces of IgM antibody or non-specific staining. Three of the patients were examined for antibody before and after a clinical recurrence of their herpes infection, but no changes in titre were recognised.

\section{Antibody responses in the serum in HSE}

Ten patients were studied, in all of whom the diagnosis had been confirmed by the isolation of herpes-simplex virus, type 1 , from brain biopsy specimens (table III). Eight of them belong to the Oxford series of HSE cases described by MacCallum, Chinn and Gostling (1974).

TABLE II

Serum-antibody levels in patients with a history of recurrent herpes

\begin{tabular}{l|cccr}
\hline $\begin{array}{c}\text { Patient } \\
\text { number }\end{array}$ & $\begin{array}{c}\text { Virus } \\
\text { type }\end{array}$ & $\overbrace{\begin{array}{c}\text { Complement- } \\
\text { fixing }\end{array}}^{\text {Antibody titres }}$ & IgG $\dagger$ & IgM $\dagger$ \\
\hline $10^{*}$ & 1 & 32 & 64 & 2 \\
11 & 1 & 64 & 128 & $<2$ \\
$12^{*}$ & 1 & 64 & 128 & $<2$ \\
13 & 1 & 64 & 128 & $<2$ \\
$14^{*}$ & 2 & 32 & 32 & 2 \\
\hline
\end{tabular}

* The same titres were obtained before and after a recurrence.

$\uparrow$ Estimated by indirect immunofluorescence.

In three patients, nos. 15,18 and 24 , serum specimens were obtained early in the disease, at a time when there was little or no detectable CF antibody. However, in all three, the presence of IgG antibody was demonstrable by immunofluorescence. Subsequently, both CF and IgG antibodies increased, in parallel, to achieve titres higher than are usually seen in non-encephalitic, primary infections. IgM antibody did not appear before IgG antibody, and reached titres of 2-16 after 12-18 days.

In five patients, nos. 16, 17, and 19-21, the first serum available already had appreciable levels of both CF and IgG antibodies. IgM-antibody titres of 8 or more were achieved within the first 3 weeks of their illness, except in patient 16 whose titre was 4 on the 13th day, when he died. Patient 23 gave a definite history of cold sores and his IgM antibody titre remained at 2 throughout the course of the illness. Of particular interest was patient 22 whose IgM antibody titre was 4 on day 8 but was $<2$ at all subsequent examinations.

Because of the possibility that high levels of IgG antibody might block the attachment of IgM antibody to infected cells in the indirect immunofluorescence test and thus lead to falsely low readings for IgM, several sera were fractionated on sucrose gradients and the IgM-containing fractions were then 
TABLE III

Serum- and cerebrospinal-fluid (CSF)-antibody titres in patients with herpetic encephalitis

\begin{tabular}{|c|c|c|c|c|c|c|c|c|c|}
\hline \multirow{2}{*}{$\begin{array}{l}\text { Patient } \\
\text { number }\end{array}$} & \multirow{2}{*}{$\begin{array}{c}\text { Age } \\
\text { (years) }\end{array}$} & \multirow{2}{*}{$\begin{array}{l}\text { Day of } \\
\text { illness }\end{array}$} & \multicolumn{3}{|c|}{$\begin{array}{l}\text { Serum-antibody titre on the } \\
\text { stated day }\end{array}$} & \multirow{2}{*}{$\begin{array}{l}\text { Day of } \\
\text { illness }\end{array}$} & \multicolumn{3}{|c|}{$\begin{array}{l}\text { CSF-antibody titre on the } \\
\text { stated day }\end{array}$} \\
\hline & & & $\begin{array}{l}\text { Complement- } \\
\text { fixing }\end{array}$ & $\mathrm{IgG}^{*}$ & $\operatorname{IgM}^{*}$ & & $\begin{array}{l}\text { Complement- } \\
\text { fixing }\end{array}$ & $\mathrm{IgG}^{*}$ & $\operatorname{IgM}^{*}$ \\
\hline 15 & 51 & $\begin{array}{r}4 \\
8 \\
16\end{array}$ & $\begin{array}{r}<4 \\
<4 \\
1024\end{array}$ & $\begin{array}{r}16 \\
16 \\
512\end{array}$ & $\begin{array}{r}<2 \\
2 \\
8\end{array}$ & $\begin{array}{r}4 \\
\dddot{17}\end{array}$ & $\begin{array}{c}<2 \\
\dddot{64}\end{array}$ & $\begin{array}{r}<2 \\
\dddot{\ldots} \\
128\end{array}$ & $\begin{array}{c}0 \dagger \\
\cdots \\
0\end{array}$ \\
\hline 16 & 29 & 13 & 64 & 64 & 4 & 11 & $<2$ & $<2$ & 0 \\
\hline 17 & 87 & 20 & 512 & 512 & 8 & $\ldots$ & $\ldots$ & $\ldots$ & $\ldots$ \\
\hline 18 & 60 & $\begin{array}{r}6 \\
18 \\
145\end{array}$ & $\begin{array}{r}8 \\
1024 \\
512\end{array}$ & $\begin{array}{r}16 \\
1024 \\
256\end{array}$ & $\begin{array}{r}4 \\
16 \\
2\end{array}$ & $\begin{array}{r}12 \\
29 \\
145\end{array}$ & $\begin{array}{r}128 \\
256 \\
64\end{array}$ & $\begin{array}{l}256 \\
128 \\
128\end{array}$ & $\begin{array}{l}0 \\
0 \\
0\end{array}$ \\
\hline 19 & 50 & $\begin{array}{r}16 \\
22 \\
44 \\
425\end{array}$ & $\begin{array}{r}512 \\
512 \\
1024 \\
128\end{array}$ & $\begin{array}{r}256 \\
256 \\
1024 \\
256\end{array}$ & $\begin{array}{r}4 \\
8 \\
4 \\
<2\end{array}$ & $\begin{array}{r}16 \\
\ldots \\
425\end{array}$ & $\begin{array}{l}64 \\
\ldots \\
\dddot{32}\end{array}$ & $\begin{array}{l}- \\
\ldots \\
\dddot{32}\end{array}$ & $\begin{array}{l}- \\
\ldots \\
0\end{array}$ \\
\hline 20 & 59 & $\begin{array}{c}10 \\
43 \\
150 \\
4 \text { yrs }\end{array}$ & $\begin{array}{r}512 \\
512 \\
512 \\
64\end{array}$ & $\begin{array}{l}512 \\
512 \\
256 \\
128\end{array}$ & $\begin{array}{r}8 \\
4 \\
<2 \\
<2\end{array}$ & $\begin{array}{r}4 \\
16 \\
43 \\
150\end{array}$ & $\begin{array}{r}<8 \\
256 \\
\ldots \\
\mathrm{a} / \mathrm{c}\end{array}$ & $\begin{array}{r}8 \\
64 \\
64 \\
128\end{array}$ & $\begin{array}{l}0 \\
0 \\
0 \\
0\end{array}$ \\
\hline 21 & 40 & $\begin{array}{r}20 \\
35 \\
133\end{array}$ & $\begin{array}{c}64 \\
128 \\
\mathrm{a} / \mathrm{c}_{+}^{+}\end{array}$ & $\begin{array}{r}64 \\
512 \\
\ldots\end{array}$ & $\begin{array}{r}8 \\
16 \\
<2\end{array}$ & $\begin{array}{r}23 \\
35 \\
133\end{array}$ & $\begin{array}{r}32 \\
128 \\
64\end{array}$ & $\begin{array}{r}64 \\
128 \\
64\end{array}$ & $\begin{array}{l}0 \\
1 \\
0\end{array}$ \\
\hline 22 & 20 & $\begin{array}{r}8 \\
14 \\
29 \\
57 \\
79 \\
149\end{array}$ & $\begin{array}{r}16 \\
2048 \\
1024 \\
1024 \\
1024 \\
1024\end{array}$ & $\begin{array}{r}16 \\
1024 \\
1024 \\
1024 \\
1024 \\
512\end{array}$ & $\begin{array}{r}4 \\
<2 \\
<2 \\
<2 \\
<2 \\
<2\end{array}$ & $\begin{array}{r}8 \\
16 \\
37 \\
\ldots \\
108 \\
\ldots\end{array}$ & $\begin{array}{r}16 \\
128 \\
64 \\
\ldots 4 \\
64 \\
\ldots\end{array}$ & $\begin{array}{r}16 \\
128 \\
128 \\
\ldots \\
128 \\
\ldots\end{array}$ & $\begin{array}{c}\mathbf{0} \\
\mathbf{0} \\
\mathbf{0} \\
\ldots \\
\mathbf{0} \\
\ldots\end{array}$ \\
\hline $23 \S$ & 62 & $\begin{array}{r}5 \\
15 \\
28 \\
72\end{array}$ & $\begin{array}{r}16 \\
128 \\
128 \\
256\end{array}$ & $\begin{array}{r}64 \\
128 \\
256 \\
256\end{array}$ & $\begin{array}{r}2 \\
2 \\
2 \\
<2\end{array}$ & $\begin{array}{l}\dddot{16} \\
28 \\
72\end{array}$ & $\begin{array}{l}\dddot{16} \\
32 \\
32\end{array}$ & $\begin{array}{l}\dddot{64} \\
32 \\
64\end{array}$ & $\begin{array}{l}\dddot{y} \\
0 \\
0 \\
0\end{array}$ \\
\hline 24 & 64 & $\begin{array}{r}7 \\
12 \\
196\end{array}$ & $\begin{array}{l}<2 \\
256 \\
256\end{array}$ & $\begin{array}{r}64 \\
256 \\
128\end{array}$ & $\begin{array}{r}<2 \\
2 \\
<2\end{array}$ & $\dddot{12}$ & $\begin{array}{l}1208 \\
128\end{array}$ & $\begin{array}{r}\dddot{64} \\
128\end{array}$ & $\dddot{0}$ \\
\hline
\end{tabular}

* Estimated by indirect immunofluorescence. $\quad \ddagger \mathrm{a} / \mathrm{c}=$ anti-complementary. $\dagger$ Negative results with undiluted CSF. $\quad \$$ Past history of cold sores. 
tested for HSV-specific IgM antibody (table IV). In most cases the fractions actually contained significantly less IgM antibody than did the whole serum from which they had been prepared. In patient 22 , however, fractionation revealed the presence of herpes IgM-antibody, apparently absent from the whole serum.

When the results were corrected by the dilution factor of the fractionation procedure the real titres obtained were similar to those found initially in whole

TABLE IV

Herpes-virus IgM-antibody titres in serum before and after sucrose-gradient fractionation

\begin{tabular}{|c|c|c|c|c|c|}
\hline \multirow{2}{*}{$\begin{array}{l}\text { Patient } \\
\text { number }\end{array}$} & \multirow{2}{*}{$\begin{array}{l}\text { Day of } \\
\text { illness }\end{array}$} & \multicolumn{2}{|c|}{ IgM antibody titres of } & \multirow{2}{*}{$\begin{array}{c}\text { Fraction-2 } \\
\text { dilution } \\
\text { factor }\end{array}$} & \multirow{2}{*}{$\begin{array}{l}\text { Corrected titre of } \\
\text { IgM in whole serum }\end{array}$} \\
\hline & & $\begin{array}{l}\text { whole } \\
\text { serum }\end{array}$ & $\begin{array}{l}\text { gradient- } \\
\text { fraction } 2\end{array}$ & & \\
\hline 17 & 20 & 8 & 2 & $4 \cdot 7$ & 8 \\
\hline 18 & 18 & 16 & 4 & $3 \cdot 1$ & 12 \\
\hline 19 & 16 & 4 & 1 & $3 \cdot 3$ & 4 \\
\hline 22 & $\begin{array}{l}15 \\
29 \\
57 \\
79\end{array}$ & $\begin{array}{l}<2 \\
<2 \\
<2 \\
<2\end{array}$ & $\begin{array}{l}2 \\
4 \\
2 \\
1\end{array}$ & $\begin{array}{l}4.4 \\
4.0 \\
3.9 \\
4 \cdot 3\end{array}$ & $\begin{array}{r}8 \\
16 \\
8 \\
4\end{array}$ \\
\hline 23 & 16 & 2 & 0 & 3.9 & $\ldots{ }^{*}$ \\
\hline 24 & 12 & 2 & 0 & 3.7 & $\ldots{ }^{*}$ \\
\hline
\end{tabular}

* Correction not possible because of zero values in fraction 2.

serum. A blocking effect had, therefore, occurred only in patient 22, whose corrected titres for IgM antibody were now similar to those found in the other patients.

\section{Antibody responses in the CSF in HSE}

Both CF antibody and immunofluorescent IgG antibody were found in the CSF of all the cases examined, except patient 16 who died on day 13. Similar titres were obtained by both methods. The antibody persisted well beyond the acute stage of the illness and in patient 19 was still present more than a year later. The ratio of serum : CSF IgG antibody in these patients ranged from $1: 2$ to $1: 10$.

Although the CSF specimens could be examined for antibody by the immunofluorescence technique even when undiluted, because of the complete absence of non-specific staining, only one of the nine patients examined had 
detectable IgM antibody in the CSF; this was patient 21 and the antibody was found only in a single undiluted specimen.

\section{DiscusSION}

Our results show that, in primary HSV infection, IgG and IgM antibodies appear in the serum at the same time and that IgM antibody persists for at least 8 weeks. In uncomplicated rubella, specific IgM antibody is present for only 3-4 weeks (Vesikari and Vaheri, 1968; Best, Banatvala and Watson, 1969) and in measles it has usually disappeared by the 6th week (Connolly et al., 1971). The more persistent response in HSV infection resembles that seen in infections with EB virus (Banatvala, Best and Waller, 1972) and cytomegalovirus (Schmitz and Haas, 1972), both members of the herpesvirus group.

Persons with recurrent herpetic infections keep more or less constant levels of CF antibody, as a rule unaffected by the reactivations (Juel-Jensen and MacCallum, 1972). This was confirmed for CF and IgG and IgM antibodies in the three patients who underwent recurrences during the present study. Because only two of the five patients with a history of recurrences had detectable IgM antibody, there is obviously no simple relationship between the persistence of this antibody and chronic herpesvirus infection.

Herpes-simplex encephalitis may occur as a primary infection, as a reinfection, or as a reactivation of latent infection (Leider et al., 1965). In the primary infections, the specific IgM antibody response in the serum is similar to that seen in non-encephalitic primary infections. The one encephalitis patient with a history of cold sores showed an unchanging IgM antibody titre of 2, despite a four-fold rise in IgG and CF antibodies. Interference by high levels of IgG antibody with the detection of IgM antibody in the serum, as occasionally seen in rubella (Cradock-Watson, Bourne and Vandervelde, 1972), infectious mononucleosis (Banatvala et al., 1972), cytomegalovirus (Schmitz and Haas, 1972) and chlamydial infections (Juchau et al., 1972), was found in only one of our cases.

The ratio of serum : CSF herpesvirus antibody in the encephalitis cases was never greater than $10: 1$, compared with a poliovirus-neutralising antibody ratio in the same patients (MacCallum, Chinn and Gostling, 1974) of $64: 1$ or more. This makes it highly likely that the herpesvirus antibody in the CSF was made locally and had not simply diffused from the blood into the CSF. The antibody in the CSF was predominantly IgG and it persisted for a long time, more than a year in one case followed for that period. This may be a useful finding for making a retrospective diagnosis.

In contrast to the findings in subacute sclerosing panencephalitis (Connolly et al., 1971), IgM antibody was not found in the CSF at any stage of the disease. In this respect herpes-simplex encephalitis in adults differs also from neonatal encephalitis due to HSV in which CSF IgM antibody has been found (Lerner et al., 1972). The failure to detect IgM antibody in the CSF provides no information about the possible persistence of HSV in the brain.

The finding of serum IgM-antibody titres of 8 or more in primary infections 
with HSV, compared with titres of 2 or less in recurrences or reinfections, may prove to be of value in the diagnosis of HSE. It may be possible to differentiate between true primary HSE and encephalitis in patients who have encountered the virus in the past and to show whether there is any difference in the severity of disease in the two groups.

\section{SUMMARY}

In nine patients with oral or genital primary herpes-simplex-virus infection, examined by the indirect immunofluorescence technique, IgG and IgM antibodies were both present by the sixth day. Significant titres of IgM persisted for 8 weeks or more. No changes in antibody titre were observed in three patients with clinical recurrences; in only two of five patients with a history of recurrences was IgM detectable, and at low levels. Eight adult patients with herpes-simplex encephalitis (HSE) showed serum IgG and IgM antibody responses similar to those seen in the non-encephalitic primary infections, although in one of the cases the IgM antibody was detected only after sucrose density-gradient fractionation of the serum. Another patient with HSE and a past history of cold sores had a low, unchanging level of IgM antibody in the serum that persisted for about 10 weeks. IgG antibody, but no IgM antibody, was found in the CSF of the patients with HSE.

I am greatly indebted to Dr F. O. MacCallum and Dr A. H. Tomlinson for continued encouragement, help and advice during this study.

\section{REFERENCES}

Banatvala, J. E., Best, J. M. And Waller, D. K. 1972. Epstein-Barr virus-specific IgM in infectious mononucleosis, Burkitt lymphoma, nasopharyngeal carcinoma. Lancet, 1, 1205.

Best, J. M., Banatvala, J. E. and Watson, D. 1969. Serum IgM and IgG responses in postnatally acquired rubella. Lancet, 2,65 .

Connolly, J. H., HaiRe, M. AND HADDEN, D. S. M. 1971. Measles immunoglobulins in subacute sclerosing panencephalitis. Br. med. J., 1, 23.

Cradock-Watson, J. E., Bourne, M. S. and Vandervelde, E. M. 1972. IgG, IgA and IgM responses in acute rubella determined by the immunofluorescent test. J. Hyg., Camb., 70, 473.

Fraser, K. B., Shirodaria, P. V. and Stanford, C. F. 1971. Fluorescent staining and human IgM. Br. med. J., 3, 707.

HAIRE, M. AND HADDEN, D. S. M. 1970. Immunoglobulin responses in rubella and its complications. Br. med. J., 3, 130.

JuchaU, S. V., LinscotT, W. D., Schachter, J. AND JAwetz, E. 1972. Inhibition of antichlamydial IgM antibody by IgG antibody in immunofluorescence tests. J. Immun., $108,1563$.

Juel-Jensen, B. E. ANd MacCallum, F. O. 1972. Herpes simplex, varicella and zoster. London, pp. 28 and 151.

Leider, W., Magoffin, R. L., Lennette, E. H. and Leonards, L. N. R. 1965. Herpes simplex virus encephalitis: its possible association with reactivated latent infection. New Engl. J. Med., 273, 341.

Lerner, A. M., LaUter, C. B., Nolan, D. C. AND Shippey, M. J. 1972. Passive haemagglutinating antibodies in cerebrospinal fluid in Herpesvirus hominis encephalitis. Proc. Soc. exp. Biol. Med., 140, 1460. 
MacCallum, F. O., Chinn, I. J. And Gostling, J. V. T. Antibodies to herpes simplex virus in the cerebrospinal fluid of patients with encephalitis or meningo-encephalitis. J. med. Microbiol., 7, 325.

SCHMITZ, H. AND HAAS, R. 1972. Determination of different cytomegalovirus immunoglobulins (IgG, IgA, IgM) by immunofluorescence. Arch. ges. Virusforsch., 37, 131.

VEsIKARI, T. AND VAHERI, A. 1968. Rubella: a method for rapid diagnosis of a recent infection by demonstration of the IgM antibodies. Br. med.J., 1, 221. 